\title{
Message from the Dean
}

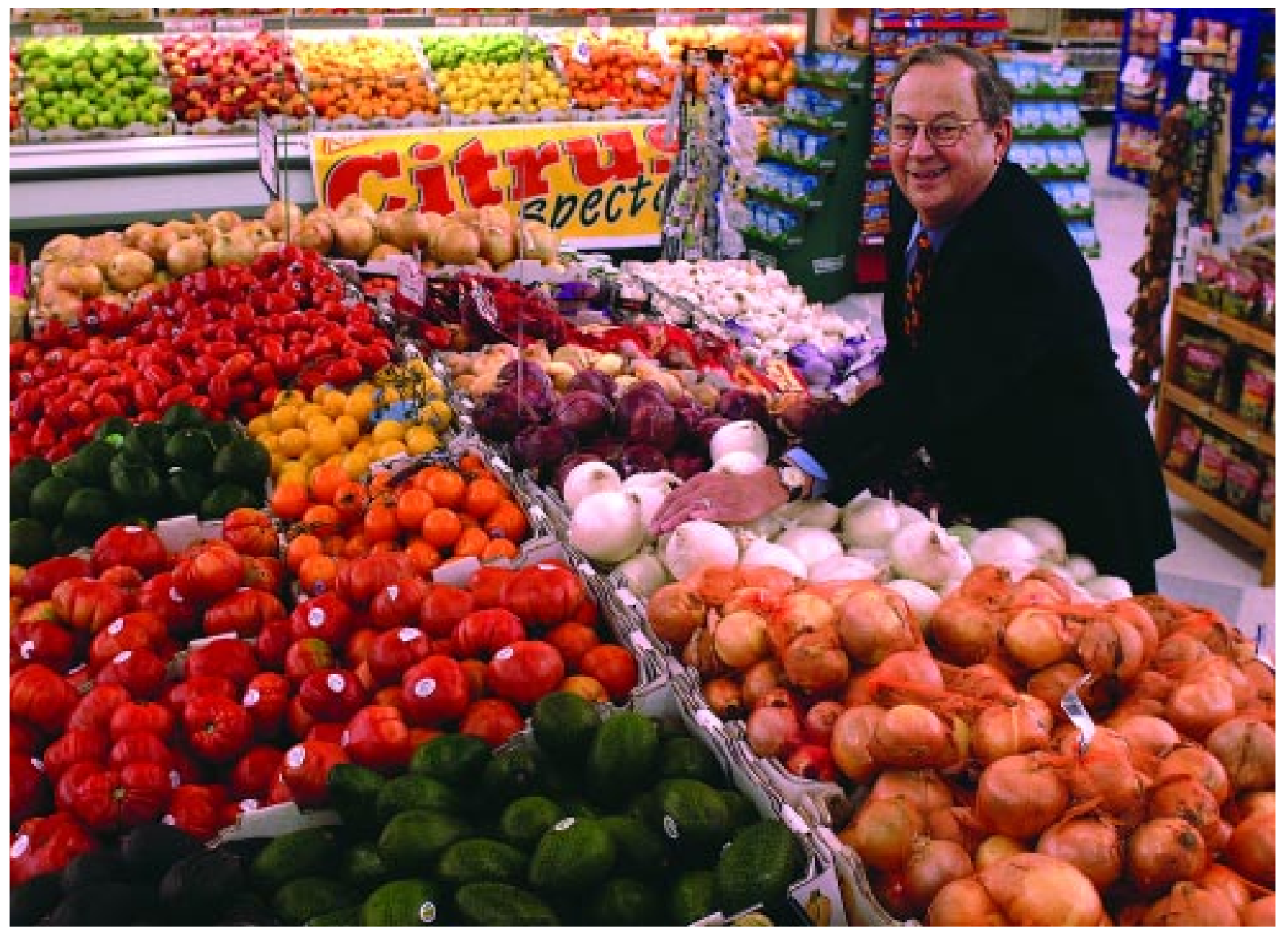

As we celebrate the University of Florida's sesquicentennial this year, it is an honor and a pleasure to introduce this publication in recognition of the enormous contributions of Florida Agricultural Experiment Station (FAES) scientists to the agricultural industries of Florida.

Agriculture is a diverse and important industry in this state. It encompasses the production of food, timber, and ornamental plants, including grasses for turf. Florida also has a large animal industry, for both food and pleasure. In total, the agricultural industry generates an economic impact of over $\$ 50$ billion per year, second only to tourism in Florida. And this will continue because Florida's warm climate will favor the expansion of high value food and ornamental plant industries to meet the nation's growing demands.

The success of agriculture in Florida, especially in plant production, has been enabled by products of research in the Florida Agricultural Experiment Station. FAES has been in business since 1888, and since then, it has released numerous plant varieties that have made possible the success of crop production in Florida. This has come as a result of the new products (varieties) and the new processes (production and protection) invented or discovered by FAES scientists. This publication focuses on the products - the new varieties that have been developed and released since 1888 .

Richard L. Jones, Dean for Research and Director, Florida Agricultural Experiment Station 


\section{Introduction}

New plants developed at the Florida Agricultural Experiment Station (FAES) have been vital to the state's agricultural industries and to consumers here and throughout the country and the world. New crop varieties are developed through research led and conducted by plant breeders with cooperation from scientists in other agricultural disciplines. These varieties may have higher yield; they may be more resistant to pests, or they may be healthier for consumers. Almost every crop variety grown in Florida came from plant breeding programs at FAES.

The FAES is the research arm of the Institute of Food and Agricultural Sciences (IFAS) at the University of -Florida (UF). The FAES mission is to discover, invent, and develop new applications of knowledge for agricultural, human and natural resources. By presenting and celebrating the many crops and plants developed by the FAES, this publication celebrates the 150th anniversary of the University of Florida and its theme - "Honoring the Past, Shaping the Future."

A look at the annual reports of the FAES reveals the early research efforts to develop the best plant varieties for Florida, a place with soils and climate unique to the U.S.

\section{Some descriptions of the first plant breeding studies at the FAES are:}
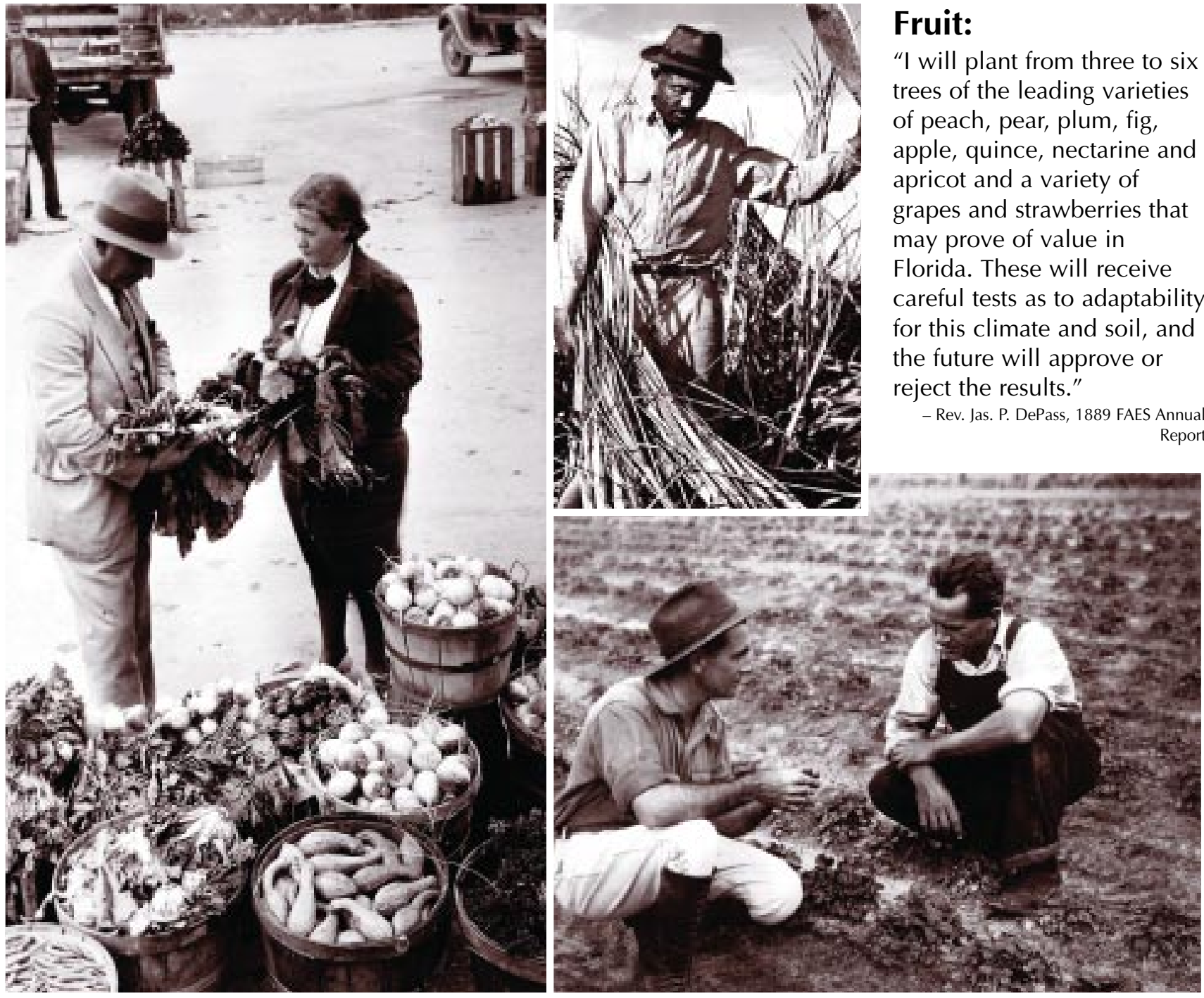


\section{Strawberry:}

"The leading varieties cultivated in the state are the Newnan, Hoffman, Cloud, Wilson and Lady Thompson. The Lady Thompson is comparatively a newcomer, but it has scored a few remarkable successes. It is prolific in a high degree and of an agreeable flavor; its greatest fault is its light color. This renders it unpopular in Boston, while in New York and Philadelphia it is said to have secured, for careful growers and shippers, some very flattering returns."

- S. Powers, 1897 FAES Annual Report

\section{Tomato:}

"During last year's experiments with blight on the experiment station grounds, Red-field Beauty was used and in only one case a plant was noted that seems to resist the blight when all others about it had been destroyed. Seed from this plant was carefully saved and further work is in progress in this particular line." - P.H. Rolfs, 1898 FAES Annual Report

\section{Corn:}

"As mentioned in the Report for 1910, a flinty corn is regarded as more suitable for South Florida than the dent varieties grown in North Florida.... This flinty West Indian or Cuban corn was crossed with three of the best dent varieties grown in North Florida. The first generation in each case, to the eye, seemed, in 1911 , superior in uniformity in the field and in total crop to its parents."

- John Belling, 1912 FAES Annual Report
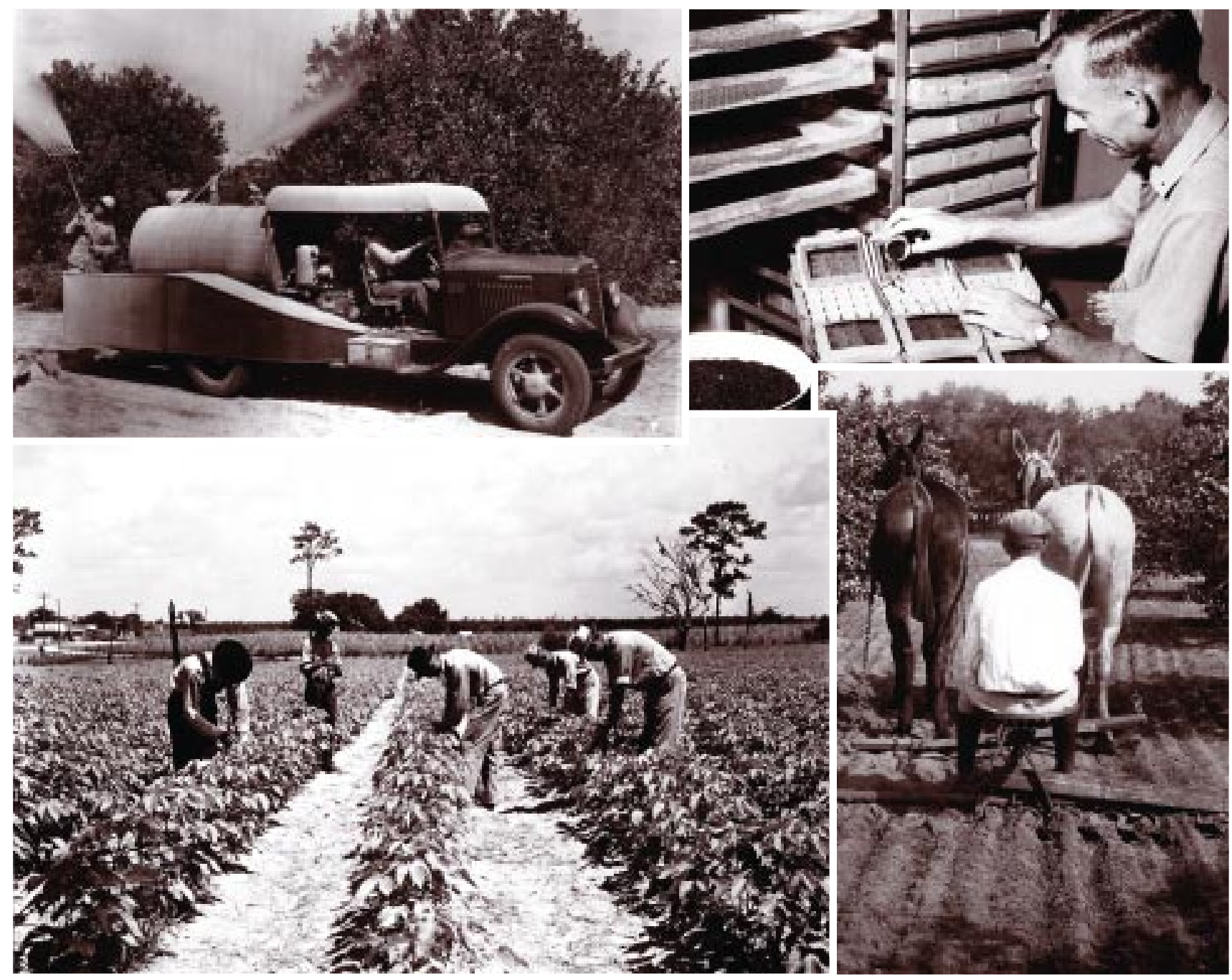


\section{Several factors have guided new plant development in Florida:}

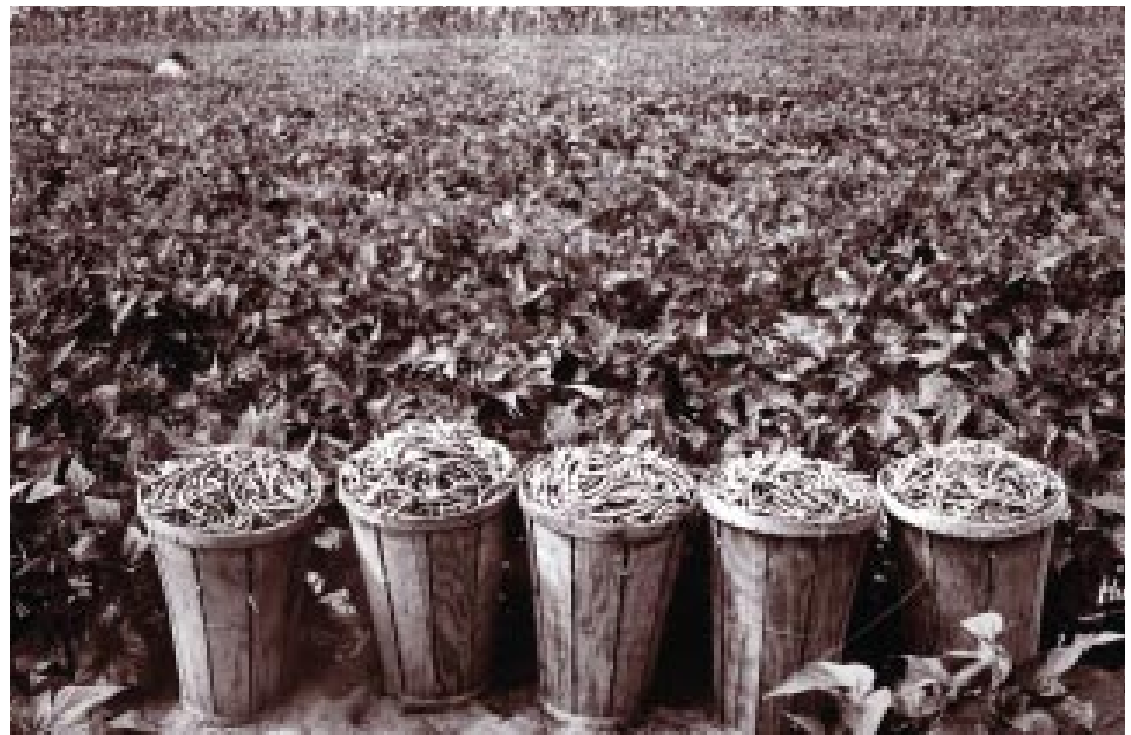

\section{Florida's warm climate:}

When northern varieties were introduced into Florida, they were not well adapted to a warm climate. FAES scientists had to breed varieties that tolerated warmer days and nights and shorter, warmer winters.

- Breeding programs since the 1950s have developed "lowchill" peach varieties - those that can grow and produce fruit with very few hours of chilling in winter.

- Breeding for heat tolerance has been critical for success of the tomato industry in Florida one variety, Solar Set, exhibits a superior flavor and was the first to have heat-tolerant fruitsetting ability.

\section{Disease and insect resistance:}

Resistance to insects and disease is critical to crop production in Florida, and all breeding programs have had resistance as a major goal.

- A major achievement in the tomato breeding program has been the development of disease-resistant varieties. The release of Walter in 1969

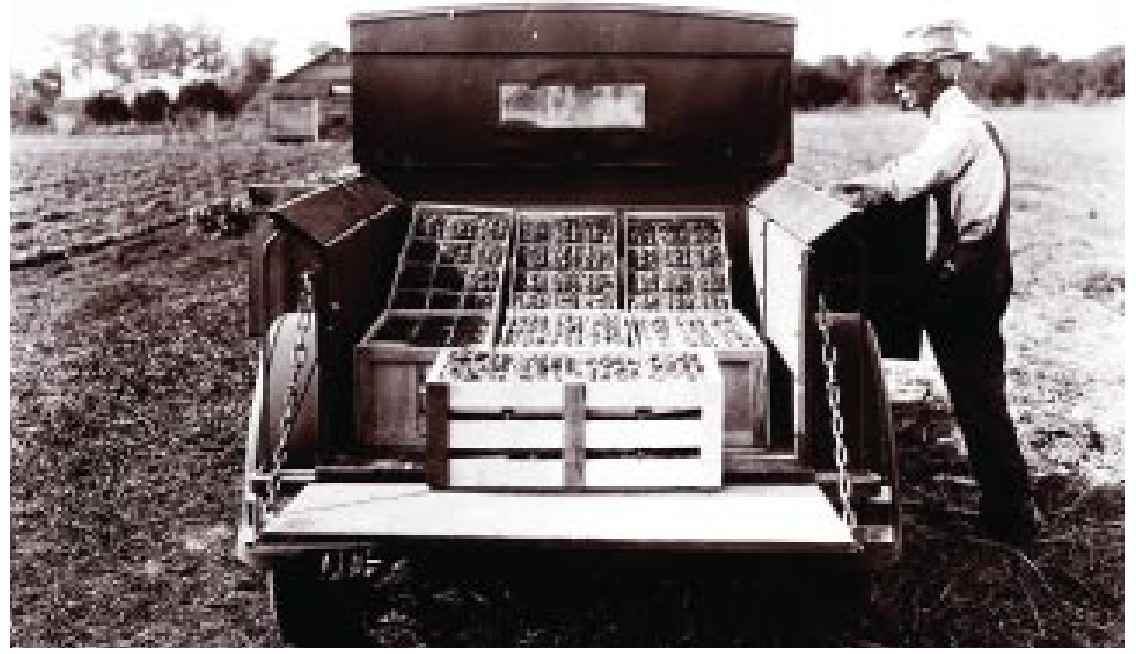

marked the world's first variety with resistance to the Fusarium wilt race 2 pathogen.

- Since 1930, watermelon varieties have been developed to resist serious watermelon diseases such as Fusarium wilt and anthracnose.

\section{New crops:}

Some new FAES crop varieties have helped create new products and enterprises for Florida.

- During the 1960s and 1970s, breeders worked to incorporate the shrunken-2 gene into sweet corn varieties, allowing Florida sweet corn to be shipped throughout the U.S. while still maintaining its outstanding sweetness and quality.

- Most of the world's caladium tubers are produced on 1500 acres in Highlands County in Central Florida. FAES varieties have resulted in an industry with a wholesale value of approximately $\$ 15$ million annually.

\section{Unique market windows:}

With its warm winters, Florida is able to grow and ship crops at times when they are unavailable elsewhere. Many crops have been bred to meet these unique market windows.

- In 1948, Ralph Sharpe, horticulturist, crossed native wild Florida blueberries with northern varieties. After nearly 30 years of crossing and selection, the first varieties were released. These new varieties had outstanding flavor, heat tolerance and were harvested in May to reach an early market window.

- Strawberry varieties that yield in December, January, and 


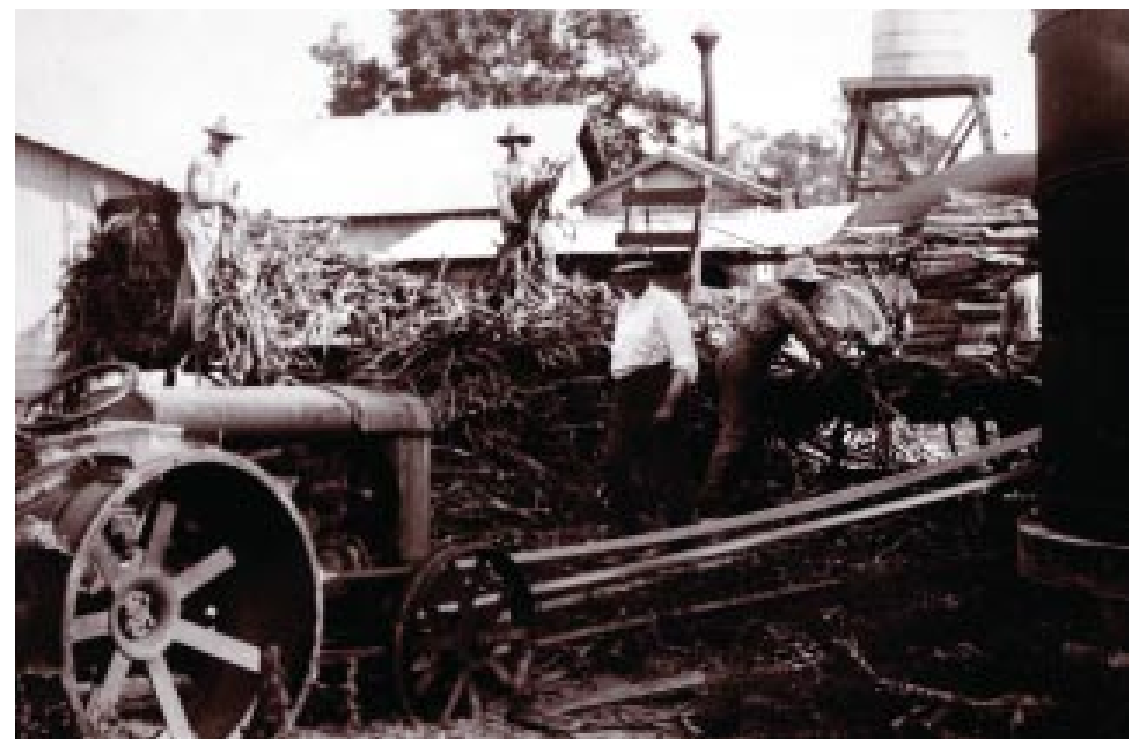

February have allowed Florida growers to take advantage of markets at a time when strawberries were not previously available in the U.S.

\section{Healthier food:}

Breeders are working with food scientists and nutritionists to develop healthier foods. As we learn more about nutritional benefits of certain foods, many opportunities will arise to breed healthier crops.

- Recent development of higholeic-acid peanut varieties in the Florida peanut breeding program will greatly extend the shelf life of peanut products. Oil from these peanuts may reduce the incidence of heart disease, thus rivaling the popular olive oil.

- Tomatoes are a good source of carotenoids, such as lycopene, that are beneficial as cancerpreventing antioxidants. FAES food scientists are joining plant breeders to test and select for high-lycopene tomato varieties.

\section{Increased productivity:}

Plant breeding has enabled higher yields for many crops, which has led to greater productivity for growers and lower costs for consumers.

- The breeding program for slash pine has resulted in 45 percent more wood per acre from slash pine plantations throughout the South.

- Horizon 314 is a livestock forage oat released jointly with the University of Georgia in 1999. Its improved yield makes it the most popular winter oat in the southern U.S.

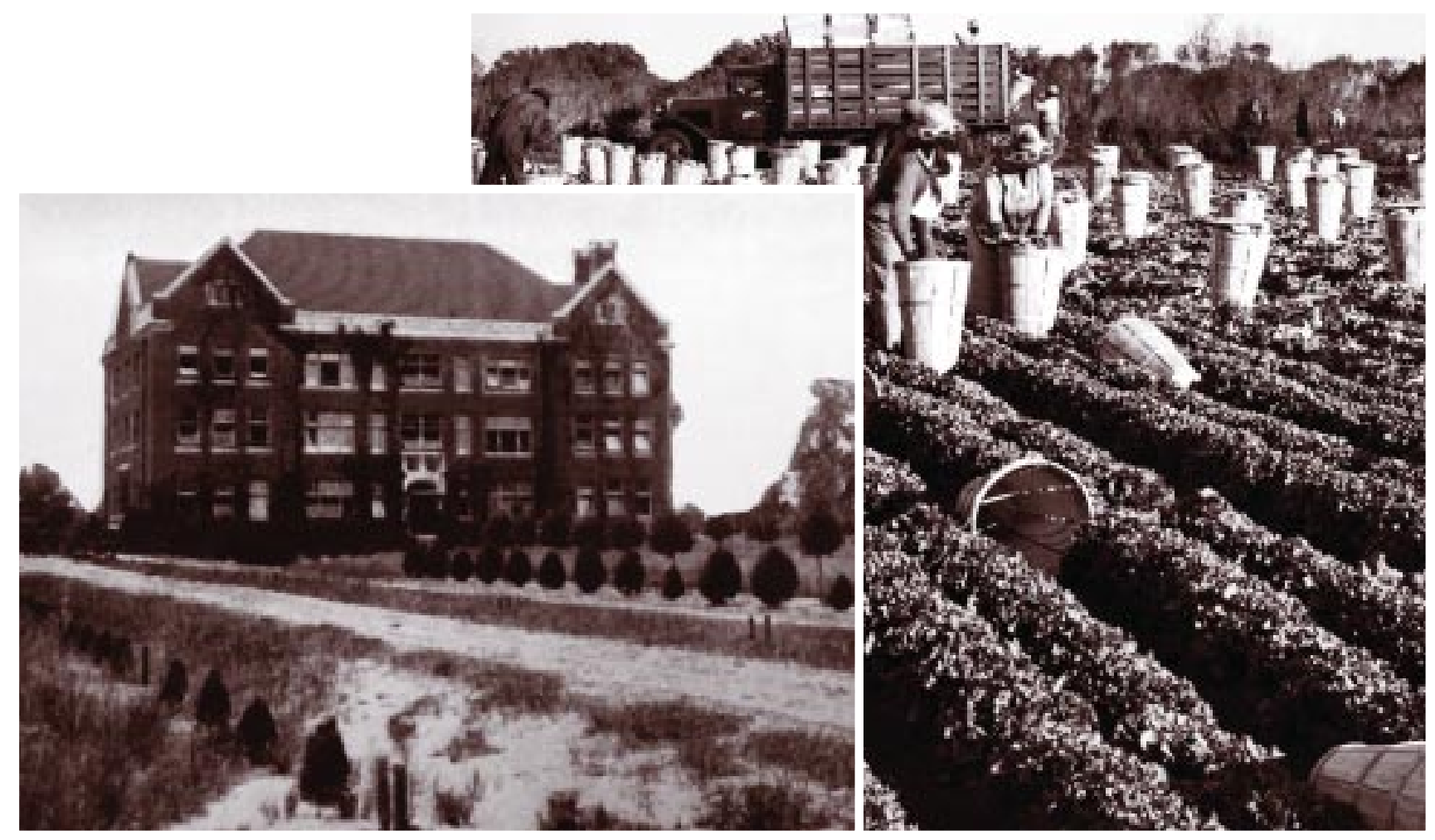

